\title{
Collaboration between Government and Civil Society: Evidence from the Implementation of Land Reform Program in Bangladesh
}

\author{
Md. Rabiul Islam \\ (Former Student of Kobe University, Japan)
}

\begin{abstract}
Land reform is a pivotal mechanism in order to improve the livelihood of underprivileged people of developing countries in the world. But the implementation of land reform programs is always a complicated issue for these countries. The reason is, in most of the cases, the governments of the third world countries more or less lack the capacity to manage the resistance created by various social groups against land reform. Moreover, the prospective recipients of land reform are not generally aware about their rights to land as land related laws and regulations in developing countries are complicated and most of the potential beneficiaries are illiterate. This study shows that in Bangladesh, public agencies can remove the above mentioned barriers and execute land reform program effectively when they work closely with civil society organizations or vice versa. The main lesson of this study is that in the developing countries, the state-society driven approach can initiate and implement distributive reform programs effectively. Furthermore, this approach promotes participatory development as well as good governance in the developing countries of the world.
\end{abstract}

Keywords: Land reform, State-society collaboration

\section{Introduction}

Land reform is considered as one of the approaches for creating an equitable society in most developing countries of the world. Actually, it provides an ample opportunity to develop an asset base for the destitute which empowers and assists them to improve their standard of living. This is why after World War II; improvement of the asset base for underprivileged people through land reform has been viewed as a fundamental policy to alleviate widespread poverty [1]. Different countries of the world have undertaken their initiatives to implement land reform programs at different times. Some of the countries have successfully implemented the programs (for example Japan, South Korea, Taiwan etc.) while other countries have failed to do so. Various political, social and economic factors are working behind the scenes. Another interesting phenomenon is that within one country some provinces have accomplished land reform more successfully than other regions. For example, in India, West Bengal and Kerala have fruitfully implemented land reform programs while states like Bihar, Tamilnadu have failed to a large extent to carry out the programs [2]. In case of Bangladesh from 1972 to 2000, 43.47\% of government agricultural land has been redistributed among landless and near landless families [3].

There are a number of obstacles working in the way of distributing agriculture government (khas) land among landless and near landless people in Bangladesh. The most important impediments are lack of information about khas land for improper and insufficient recording of rights and maps, lack of awareness among landless people about their rights to khas land, illegal occupation of khas land, absence of transparent processes to identify khas land as well as landless families, a low level of technical support and capacity, and failure to control corruption at the local level [3], [4]. [5]. One fascinating dimension is that although all upazilas ${ }^{1}$ (sub-districts) of Bangladesh are working under the same laws, rules and regulations, the distribution rate of government agriculture land among landless and near landless people is not identical in all upazilas.

Local administrations of some upazilas have successfully overcome the said barriers, through working closely with civil society organizations associated to land reform activities in Bangladesh, and have distributed more than $70 \%$ of their government land, while local administration in many other upazilas have allocated less than $30 \%$ of their khas land. So, the problematic area for this study is how some upazilas of Bangladesh have become successful in implementing land reform program while other upazilas have failed to execute the program. The purpose of this study is to ascertain and explicate the factor(s) influencing the differences in performance of different sub-districts regarding implementation of land reform program in Bangladesh.

\footnotetext{
${ }^{1}$ Upazila (sub districts) is the second tier of rural local government in Bangladesh. Right now, land reform program is going on in 446 upazilas of 61 districts.
} 


\subsection{Meaning of Land Reform}

\section{Literature Review}

In literature, the term 'land reform' has been discussed in two ways; narrow and broad. In narrower sense, land reform means an approach to provide land to the landless or near landless people. In broader sense, land reform is a comprehensive program intended to eliminate obstacles in the way of social and economic development of poor people arising out of defect in the agrarian structure of a country [6] and [7]. Land reform is very much related with the intervention in the prevailing pattern of land ownership, control and usage [8]. It is designed to reallocate power, income, social status and incentives, especially by governmental initiatives [9].

Land reform is an instrument proposed normally by governments to ensure social justice in terms of access to land, to improve productivity and to reduce poverty [10] and [11]. Thus, land reform means the redistribution of land ownership among citizens of a country under the control of government to ensure the access of landless people to government and non-government land, to increase production and to lessen the degree of poverty of that country. Analysis of above definitions also endows us with two phases of land reform; first phase- collection of land from the owners who have excess land. It is done through fixing the ceiling on land holding. In second phase, government distributes the collected land among landless and near landless people. This study considers the amount of government (khas) land distributed among the landless and near landless people as dependent variable.

\subsection{Methods or approaches of land reform}

The existing literature on land reform demonstrates that different methods and techniques are used to implement land reform programs. The commonly used methods for land reform are government/state directed land reform, society/community led land reform and market based land reform [12], [13] and [14] . Borras [15] said that four views are working all around the world for land reform. These are state-led land reform, societyled land reform, market-led land reform and state-society driven land reform. In the State-led land reform approach the main emphasis is given to the role of policy makers and state agencies responsible to carry out land reform programs. It is a top down approach under which land reform programs are designed by national governments and implemented by their administrative branches working at the local level [11]. Here, the strong political will of the state is essential and peasants and other social forces are considered as necessary administrative adjuncts of the state [15]. Major limitations of this approach are: a) It overlooks the local system of property rights, b) corruption of officials may obstruct opportunities for citizens to get equal treatment, c) limited resources of government and d) sometimes this approach suffers from lack of support of relevant local actors [16] and [11]. However, the role of the state is still important in formulating and implementing land reform program because the state is the only legitimate body to articulate and implement public policy relating to different issues of a country. It has also sufficient power to adjudicate conflicts among citizens. In addition, only a state enjoys monopoly over the lawful use of coercive force within its territory. Sometimes, it also provides technical and financial support to the peasant community. As a result, without the involvement of the state, land reform becomes impossible, regardless of any popular demand for land reform by the landless people or sufficient donor pressure [17]. The most successful state-led land reforms have been taken place in Japan, South Korea and in Taiwan.

Society-led land reform approach is just the opposite of the state-led technique, well known as being a bottom up approach. In this approach, emphasis is given on peasants and their organizations. Under this process, it is believed that the state is confined to the interest of the social elite and land markets are also dominated by influential persons of the society. So, peasants and their organizations have to take initiative to implement land reform program of a country [15]. Here peasant organizations, NGOs and political movements put pressure on the state and the state reacts with political demands originated at the local level. As a result, social mobilization from below sets the parameters of reform and the state actors only react to this bottom up pressure [11]. Scottish land reform is the perfect example of society led land reform. In this reform, communities were allowed to purchase the lands to which their ancestor historically enjoyed rights [18].

Market-led land reform approach is also known as the negotiated land reform approach. In this strategy, main emphasis is given on land market and the buying capacity of the landless or near landless people. Under this system, the state and donor agencies normally increase the buying capacity of landless people by providing favorable loans, grants, subsidies or other kinds of financial support and landless people become able to buy land from land market. Currently South Africa, Brazil and Colombia are practicing it with the help of the World Bank and other international organizations [11]. Main advantages of this approach are: a) it is widely accepted by stakeholders and b) it is also less costly to implement. Major disadvantages of this approach are: a) the market led approach is difficult to employ in the cases where distribution of land among citizens is highly asymmetrical and b) it sometimes assists powerful landowners to strengthen their control instead of benefiting small producers [10 and 19]. 
State-society driven land reform approach is the combination of both state and society led approaches. There are some limitations and weakness of both state-led and society-led land reform strategies. The first one overemphasizes the capacity of the policy makers and implementers to overcome the power of land lords and other social groups whereas the second one exaggerates the power of peasant organizations by neglecting the role of government in conceptualizing and implementing land reform programs. This is why in a state-society driven approach; the main emphasis is given to the cooperation between state agencies and civil society organizations [15 and 20]. Under this approach, the successful implementation of land reform programs depends on the fruitful collaboration between government and civil society. Many scholars and multinational organizations also said that partnerships or joint- programs between government and civil society can facilitate the implementation of land reform programs. It is observed that implementation of reform programs has been slow or ineffective; unless there is cooperation between popular mobilizations within the peasants communities combined with outside pressure and government efforts [10]. Peasant organizations and their supporters (NGOs and donor agencies) play an important lobbying and catalytic role, but the fulfillment of peasants' demand ultimately depends on the activities of the government [21]. In implementing land reform programs, the role of government is the key. The reason is that among the players only government has the authority to command compliance. Government alone may be able to execute some functions of land reform but it needs the support of civil society to accomplish meaningful reform [22]. IFAD also asserts that civil society organizations can assist government to implement land reform programs in two ways: a) they can help the government to enable poor people to participate in the land reform process. It is very essential because land reform becomes more successful when beneficiaries (poor and marginal people) themselves actively participate in the implementation process, b) civil society organizations can also provide direct support for the implementation of government policies, help disseminate information, conduct research and help mobilize opposition to elitist policies. Government and civil society organizations are needed to work together to scale up the benefits of land reform by securing the access of rural poor people to land [23].

In Bangladesh, government land ${ }^{2}$ without any monetary value is allocated among landless or near landless people, thus the market has no role to play. As the ownership of the land remained with government, so without the involvement of government, land distribution is not possible. Historically, peasants' movements of Bangladesh are short lived, sporadic and under the control of non peasant outsiders hence land reform of Bangladesh cannot be absolutely explained by a society-led approach. As agents of the state, although local administration (mainly bureaucrats) are distributing land, they are not the sole actor in the process. Beside bureaucrats, civil society organizations (mainly landless peasant organizations and related NGOs) are also playing an important role. According to the Association for Land Reform and Development [24], in Bangladesh, 273 Peoples' Organizations (POs) and NGOs are actively working to establish the rights of poor people to government land. Huda said that in Bangladesh, the government, together with NGOs, has been distributing khas land among landless people since 1984. Mannan [25] asserts that in Bangladesh, NGOs have been intensely participating in order to mobilize landless and near landless people on land issues for three decades. So, state-society driven approach is the best method that can better explain the case of land reform program in Bangladesh.

\subsection{Collaboration}

The term 'collaboration' is used synonymously with the words 'cooperation' and 'partnership'. Collaboration means assisting one another to achieve specific objectives. Collaboration is a process whereby independent organizations intentionally work together to attain their objectives or for mutual benefit [26] and [27]. Collaborative governance is a kind of arrangement where public agencies work directly with non state stakeholders (like civil society) in a collective decision making process in order to make or implement public policy [28]. Collaboration may be either issue based or multi-sectoral based. In issue based collaboration, attention is given on diverse aspects of one issue such as education, whereas in multi-sectoral based collaboration, focus is concentrated on different issues in order to achieve one objective. Again, collaborations may be either for formulating public policy or for implementing public policy. Collaboration may be initiated by government or by civil society. When one actor compels other actor to engage in collaboration then it is called 'forced marriage'. As a key player of civil society, sometimes NGOs are involved in collaboration with governments of developing countries. This trend is almost equal in every region of the world [29]. GovernmentNGOs collaborations are of three kinds. In the first type, the NGO helps government to introduce participatory approaches in different development projects. In the second category, the NGOs facilitate the implementation of

\footnotetext{
${ }^{2}$ In this study, government land, well known as khas land, means the land owned by the Ministry of Land of Bangladesh. The main source of this land is the ceiling surplus land collected from large landholders.
} 
large government programs. In the third type of collaboration, government and NGOs originate alternative delivery systems and frameworks in order to provide certain types of service to certain classes of people [30] and [31]. Government-NGOs collaboration has achieved some successes in six Asian countries, namely Bangladesh, India, Thailand, Nepal, Philippines and Indonesia [32] . In Argentina, NGOs are working with local governments to implement education and training programs for low income youth, and in El Salvador, NGOs and government are collaborating with fishing cooperatives in order to facilitate overall economic development programs [33].

In developing countries, collaboration between government and civil society is essential to utilize the 'comparative advantage' of both government and civil society. On one hand, government has the authority to formulate public policies but lacks the capacity and the resources to implement the policies. On the other hand, civil society is not empowered to make laws and rules but has the capacity to mobilize rural people and can work effectively at the grassroots level [34]. As a result, through collaboration civil society gets an opportunity to expand the scope of their operations, to broaden their influences and to participate in the formulation of public policy whereas government can implement public policies effectively and efficiently, neutralize potential opposition and maintain a hold on donor funds [35].

\section{Theoretical Framework}

Fox [36] said that in developing countries, states may be able to initiate distributive reforms but their capacity to carry out reform programs largely depends on the mobilization of the beneficiaries themselves. Because anti reform interests are well-established in the state apparatus and they cannot be offset by pressure only from above or from below. Therefore, he puts emphasis on state-society cooperation in order to execute distributive reform. His approach is neither top down nor bottom up rather a mixture of the two. He terms his approach as the "Sandwich Strategy". The key actors of this approach are the relations being maintained between state and society. Evans [37] asserts that 'active government and mobilized community' together can increase their capacity in order to implement their development programs. He terms this approach as "statesociety synergy". This kind of synergy is constructible even in more unfavorable situations of developing countries. He also argues that synergy is normally based on 'embeddedness' but the concrete form of synergy includes both 'complementarity' and 'embeddedness' because it connects citizens and public officials in order to pursue their common goals. Wolford [38] advances further and asserts that cooperation between state and non state actors not only ensures proper implementation of land reform but also promotes participatory democracy by 'default rather than by design'. Ansell and Gosh [28] develop a model where they show how private stakeholders work together with public agencies to engage in consensus oriented decision making. They have identified five variables: the prehistory of cooperation or conflict, the incentives for and constraints on participation, power and resource imbalance, leadership and institutional design which determine cooperation between state agency and private stakeholders.

This study argues that collaboration between local administration and civil society actors is essential for successful implementation of land reform program in Bangladesh. So, the upazilas which are able to employ the higher level of cooperation between local administration and civil society can distribute more land than the upazilas which have failed to do so. This study also argues that among the above five variables, the prehistory of cooperation or conflict between government and civil society, and the incentives for or constrains on participation largely determine the nature of collaboration and the outcomes of land reform program in Bangladesh. The other three variables are almost similar in all upazilas of Bangladesh. So, the analytical framework of the study is as follows: 
Figure 1: Analytical framework for the study

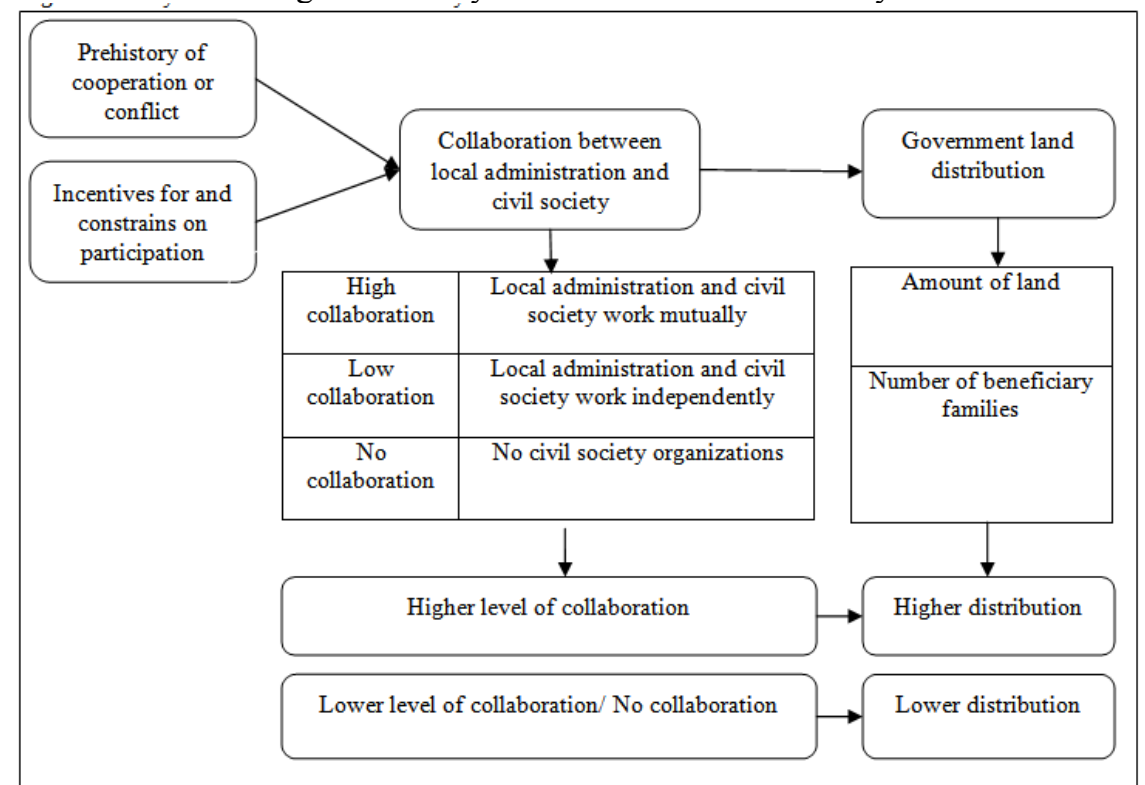

Source: Drawn by the author, 2011

\section{High collaboration, low collaboration and no collaboration}

Land reform activity mainly includes building awareness among landless and near landless people about their rights to land, identification and collection of ceiling surplus land from large landholders, selection of genuine landless people for the land and providing credits and agricultural inputs to cultivate the land [39]. In developing countries, public agency and civil society actors are involved in order to carry out the above mentioned activities separately or jointly. In this study, when the actors (local administration, peasant organizations and related NGOs) indirectly cooperate with one another, then it is designated as a lower level of collaboration. When the actors directly cooperate with one other in order to perform land reform related activities, then it is considered as a higher level of collaboration. For the lower level of collaboration, the presence of the activities of land reform related NGOs and peasant organizations is required but for the higher level of cooperation, they need to perform the activities mutually with local administration and/or to be involved in the decision making process. No collaboration means the absence of the activities of land reform related NGOs and peasant organizations. The hypothesis of the study is: the higher level of collaboration between local administration and civil society can accelerate the implementation process of land reform program in Bangladesh.

\section{Case Studies Of Government Land Distribution In Bangladesh}

To test the hypothesis of the study, two local government units (Tala upazila and Shahzadpur upazila) have been selected as cases. Tala upazila is a successful case and Shahzadpur upazila is an unsuccessful case for the study. The criteria for selection of the cases are: a) the socio-economic conditions of both the sub districts are the same, b) land holding patterns are similar, c) laws and regulations regarding land distribution are also same but the level of success and failure, in case of land distribution, are distinctly different.

\section{Land distribution in Tala upazila}

In compliance with the implementation of land reform program of the state, local administration of this upazila had started to distribute government (khas) land among landless and near landless people in 1983. From 1983 to 2009, in this upazila a total of 1,515.96 acres of khas land has been distributed among 2,956 landless families. However, the rate of distribution of khas land has not been the same over the years. In some years, the distribution rate was five to ten times of the average distribution whereas in other years, there were no distributions of khas land. The overall distributed land in different periods and undistributed land of this upazila can be shown in the following way: 
Figure 2: Graphical presentation of distributed and undistributed land in Tala (in percentage)

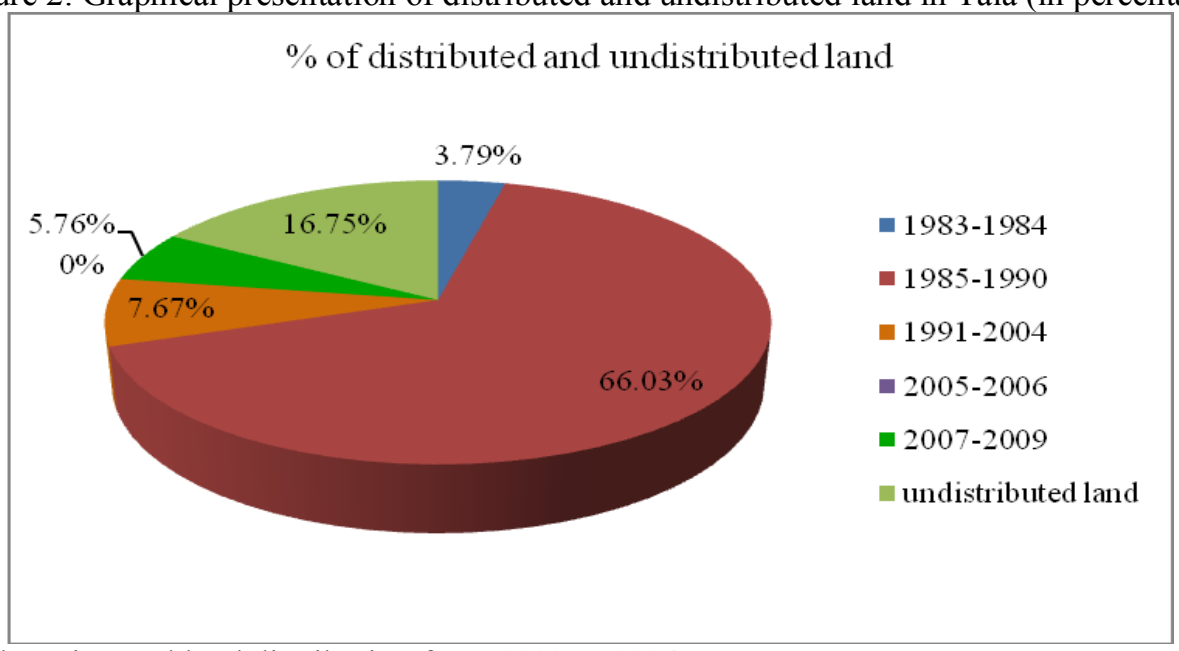

Level of collaboration and land distribution from 1983 to 1984

From 1983 to 1984 there was no collaboration between local administration and civil society. The reason was at that time, no civil society organizations were involved in land reform activities of this upazila. As there were no civil society organizations, local administration alone had identified government (khas) land, disseminated information about the distribution of khas land, received applications, scrutinized the applications, selected eligible landless people and distributed khas land among landless and near landless people of the upazila. At that time, although there was huge khas land, the amount of land distribution was not so high.

Level of collaboration and land distribution from 1985 to 1990

In this period, there was a high level of cooperation between local administration and civil society. The reason was one locally based organization, Uttaran, started working and cooperating with local administration in 1985. The collaboration process between local administration and Uttaran was like this: Uttaran was committed to building awareness among landless and near landless people about their rights to government land. It also used to encourage them to form organizations, to identify government land and to apply to the local administration to receive the land. At the initial stage, few landless people had formed organizations, identified government land and applied to the local administration for allotment if the land had not been occupied by illegal occupiers. Local administration had positively responded to this endeavor and allocated the applied land to the landless people who had identified the land. If the land was occupied by illegal occupiers, landless groups, together with Uttaran, informed the local administration about the land and illegal occupiers. Local administration used to check the records in order to ascertain whether their information was true or not. If the information was true, local administration had positively responded to their endeavors and issued legal notice to illegal occupiers to leave the land. After issuing legal notice, landless groups occupied the land and applied to the local administration for allocation. Uttaran used to help landless people to fill in the application forms and local administration allocated the land to those people who had identified and recovered land from illegal occupiers $^{3}$.

As a result, participation in the land distribution process had enabled landless people to receive land. As they received land as an incentive for participation, other landless people of the area also felt encouraged to form more organizations and to participate in the land distribution process in order to acquire government land. In some areas, landless people were organized in different groups usually comprised of $12-20$ members. These groups were mostly based on village or mouza as khas land of one village was mainly distributed among the landless people of that village. As all the members of such groups were local inhabitants, they knew well about the location of government land. In case of illegal occupations, they usually took the assistance of local administration to evict illegal occupiers ${ }^{4}$. Moreover, distribution of government land received new momentum in 1987 when the government of Bangladesh for the first time had decided to involve NGOs directly in both pre and post land reform activities. The government ensured the involvement of NGOs into land reform process through promulgation and execution of Land Reform Action Program (LRAP). As per LRAP, the government sought assistance and cooperation from NGOs in various fields, namely : As a member of upazila land reform committee, NGOs were expected to assist local administration in identifying khas land and in recognizing

\footnotetext{
${ }^{3}$ Director of NGO Uttaran has been interviewed over telephone on April 9, 2011

${ }^{4}$ Local coordinator of NGO Uttaran has been interviewed over telephone on April 10, 2011.
} 
genuine landless people for the land; they were also required to organize different programs to create consciousness about the program at village level; assist landless people to form landless cooperatives and to collect information from them about illegal occupiers; to assist local administration in surveying khas land; to assist beneficiaries by providing means of production and grants for their rehabilitation; to provide education on agriculture and development; and to support landless cooperatives to build infrastructure for transport, marketing and storage of agricultural products[3]. As the initiative was taken by autocratic government and NGOs were given preference over political parties and other elite groups, NGOs also availed the opportunity in order to secure and control political positional advantage over others and took part in land reform programs jointly with local administration in different parts of Bangladesh. As a result, in Bangladesh as a whole, 189,274 acres of land had been distributed among 199,660 households over a period of only two and half years [4].

Level of collaboration and land distribution from 1991 to 2004

In this period, there was a lower level of cooperation between local administration and Uttaran. The reason was, in 1991, there was a national election in Bangladesh and there was also a change in power of the state through the election. However, that election did not come automatically. Political parties along with civil society organizations needed to struggle intensely in order to dislodge the authoritarian rule of President Ershad (1982-1990). Actually, the movement against the Ershad regime was a joint platform among three political parties, namely Bangladesh Awami League, Bangladesh Nationalist Party and Bangladesh Jamaat-e-Islami, and civil society organizations [40]. But, some of the civil society organizations did not participate in the movements. Rather, they were working closely with the President Ershad government. After the election, Bangladesh Nationalist Party (BNP) formed the new government. This government blamed those NGOs for their relations with the Ershad regime and stopped cooperation with the NGOs [41]. As a result, after 1990, Uttaran was no longer a member of the upazila land distribution committee and did not get cooperation from local administration. Thus, the prehistory of cooperation with the military autocratic Ershad government from 1985 to 1990 hindered the cooperation with democratic government after 1990. In this period, as the level of collaboration between local administration and Uttaran was low, land distribution from 1991 to 2004 was also low.

However, after 1990, in the next several years, there were some distributions of khas land. The reasons were the continuous effect of collaboration and the active role of local administration. Although, the distribution rate was not so high, the process was continuing up to 2000. Meanwhile, two important events had happened. On one hand, most of the government land had been distributed during the years from 1985 to 1990. On other hand, although about 2,000 landless people received government land; many other landless people (about $17,000)$ remained landless. As a result, many landless groups wanted to receive the same allotment of remaining land. So, there were many conflicts concerning occupying government land. Different landless groups also made allegations against each other about their eligibility of receiving land. In such situations, the local administration had decided to stop distribution of khas land among landless in 2001.They also decided that they would not distribute land until the final list of eligible landless people was prepared. In the next several years, several government officials had changed through government mandates but they could not finalize the lists for lack of human and financial resources ${ }^{5}$.

Level of collaboration and land distribution from 2005 to 2006

In this period, there was high level of collaboration between local administration and Uttaran in order to prepare a complete list for all eligible landless people of this upazila. The reason was Uttaran could reestablish its relations with local administration in 2005. This had been possible for a project ${ }^{6}$ taken by Uttaran funded by donor agency. Under this project, after a long process of consultation with local administration, an extraordinary meeting of the Tala upazila agricultural khas land management and distribution committee was held on August 11, 2005 chaired by then Upazila Nirbahi Officer (UNO). Uttaran also participated in the meeting [42]. In that meeting, local administration and Uttaran mutually took two decisions in order to solve the problem of preparing a final list for eligible landless people. The decisions were: a) to form two special committees to scrutinize and select eligible landless people, and b) Uttaran will provide both financial and technical assistance for these committees. As per the decision of the meeting, two unique committees were formed and these committees finalized the list of all landless in 2006. As per the list, 17,178 landless people or household of this upazila were entitled to receive government land. Uttaran had also collected the maps of villages and distributed the duplicate copies of the map to the land offices working at the union level. Uttaran

\footnotetext{
${ }^{5}$ Former Assistant Commissioner (land) has been interviewed over telephone on April 22, 2011

${ }^{6}$ The name of the project was Asserting Popular Access and Rights to Resources in Southern Bangladesh (APAR). In 2004, Uttaran initiated the project in order to establish the rights of landless people to khas land. The project area included 9 upazilas of Satkhira district and 6 upazilas of Khulna district. It was funded by Manusher Jonno Foundation (Islam, n.d.:2).
} 
did it with the help of the upazila administration. These maps helped local offices as well as beneficiaries (landless people) to identify government land. Uttaran has termed the total process as the "Tala Model". Under this model, local administration and Uttaran were working together to implement land reform programs without any formal agreement between them [35].

Level of collaboration and land distribution from 2007-2009

As the list of landless people had been finalized at the end of 2006, the local administration of Tala upazila had started again the distribution of government land among landless and near landless people in 2007. In this ongoing process of distribution, local administration has been following the list prepared by joint efforts of Uttaran and local administration. Uttaran provides fees for registration of transfer deed and offers different kinds of credit facilities to beneficiaries for cultivating the land and other income generating purposes ${ }^{7}$.

According to Khan and Ahmed [43], Uttaran is also mobilizing landless people to form associations and is taking control of government land from illegal occupiers. After removing illegal occupiers from the land, the lands are distributed among landless people under government supervision. They also said that in the Satkhira and Khulna regions, Uttaran organized about 1400 landless groups representing 28,000 households. These groups have recovered 9,406 acres of land which have been distributed later on among landless people. The leader of a landless group, Dighirpara landless samity, said that all the members of this group have received government land within the last three years with the help of local administration and Uttaran. After obtaining the land, Uttaran has provided them interest free loans. They are required to pay back the loan on a monthly instalments basis ${ }^{8}$.

So it is evident that in this upazila, local administration, NGO Uttaran and landless groups were working jointly in order to distribute khas land among landless and near landless people in the periods from 1985 to 1990 and from 2007 to 2009 . As a result, the distribution rate of government land in these periods was really high. From year 1991 to year 2004, they used to work independently, consequently the allocation rate of government land among landless and near landless people was low.

\section{Land distribution in Shahzadpur upazila}

Although this upazila had started its operation in 1982, but before 1985, it could not distribute government land to landless and near landless people of this upazila. From 1985 to 2009, only 198.93 acres ( 1 hector $=2.47$ acres) of land has been distributed among 895 landless families. The overall distributed land in different periods and undistributed lands of Shahzadpur upazila can be demonstrated in the following chart:

Figure 3: Graphic representation of distributed and undistributed land in Shahzadpur upazila (in percentage)

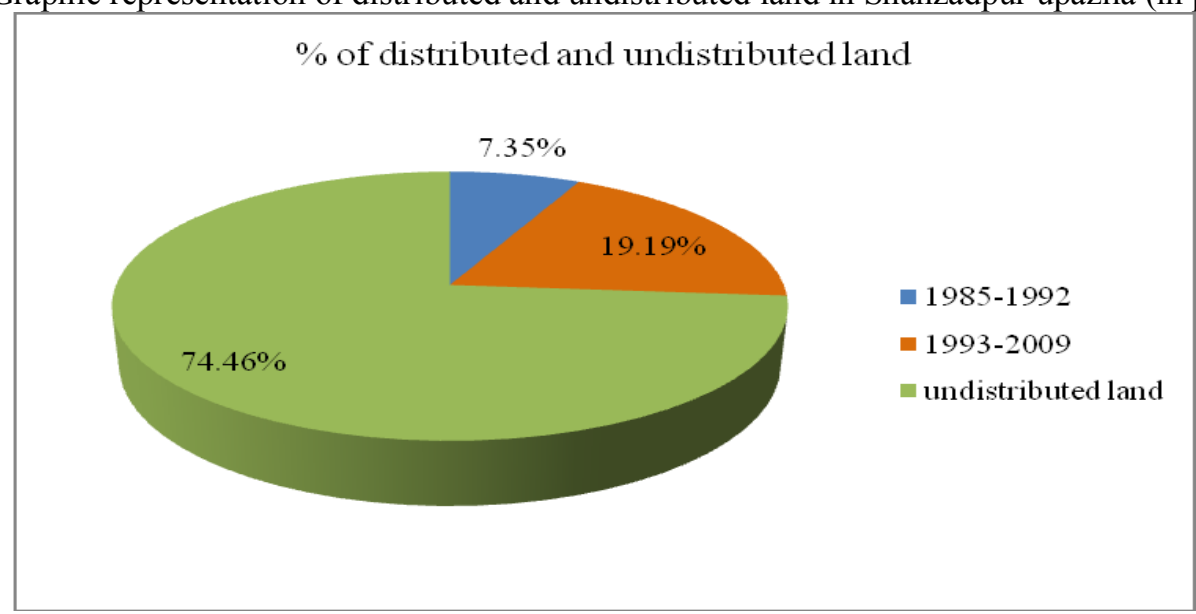

Source: Drawn by the author, 2011

Level of collaboration and land distribution from 1985 to 1992

In this period, there was no collaboration between local administration and civil society. The reason was in this period, no civil society organizations were involved in land reform activities of Shahzadpur upazila.

Although many NGOs had emerged in the 1980s and 1990s, almost all of them were engaged mainly with micro credit programs. They were not interested to participate land reform activities as it required confrontation with local power structures and few donor agencies were interested to channel funds to this sector

\footnotetext{
${ }^{7}$ Upazila Nirbahi Officer (UNO) has been interviewed over telephone on April 27, 2011

${ }^{8}$ Leader of dighirpara landless samity has been interviewed on May 14, 2011.
} 
[39]. So in that period, local administration used to distribute khas land among landless and near landless people at their own initiatives. Land distribution of this upazila received some momentum from year 1987 to 1989 as a result of special initiatives taken by government by introducing land reform action program in $1987^{9}$. But the level of success of land distribution was not as high as that of Tala upazila since there were no collaborative efforts of local administration and civil society organizations for distribution of khas land among landless and near landless people of the upazila.

Level of collaboration and land distribution from 1993 to 2009

In this period, there was a low level of collaboration between local administration and civil society. The reason was although an outsider NGO Samata had started its activities in this upazila in 1993, the operational procedure of Samata was different from that of Uttaran. In 1993, the staff of Samata had selected only two villages for its operation. They had identified the landless people of the villages and divided them into several groups. They had arranged various meetings in order to make them aware of their rights to khas land. With landless people, they had identified khas land but they saw that most of the lands were occupied by local influential persons. Like Tala upazila, Samata and landless people of Shahzadpur upazila did not inform the matter to the local administration and did not take the assistance of local administration to remove illegal occupiers. Rather they tried themselves to do it. As their capacity was limited, they could not free most of the land. In some cases, Samata helped landless people to fill in the application forms. Some of its members got khas land and while others did not receive land. In later stage, in every year Samata had expanded its operation but it could not cover even half of the villages of this upazila even of the present time ${ }^{10}$. The director of Samata also said that local administration does not co-operate with his organization in receiving land for landless people. Samata does not have any collaborative relation with local administration in respect of distributing khas land among landless and near landless people ${ }^{11}$. The Assistant Commissioner (land) also said that that the respective union parisad chairman actually determines whether a person is genuinely landless or not. The Chairman does it by providing a certificate in favor of only eligible landless people and the upazila land distribution committee considers the certificate as authenticated proof for genuine landlessness and distributes land among landless. Like Uttaran of Tala, Samata was not a member of upazila landless selection committee. As Samata did not have any role in selecting landless people, so all the members of Samata could not manage to receive khas land. This discourages other landless people to become a member of Samata and take part in land distribution process. This is why, in this period, the rate of land distribution was not as high as required.

\section{Comparative Discussion Between Two Cases}

If we critically analyze two cases (Tala upazila and Shahzadpur upazila) we can see that in Tala upazila, there was an excellent collaboration between local administration and NGO Uttaran before 1991. Both of them assisted one other in order to distribute khas land among landless and near landless people. Uttaran built awareness among landless people and inspired landless people to organize groups, to identify government land and to recover land from illegal occupiers. As per encouragement of Uttaran, the landless people identified land and illegal occupiers of khas land. Uttaran and landless groups also informed local administration about khas land and their illegal occupiers and local administration reciprocated them through providing legal notice to illegal occupiers. After providing legal notice to illegal occupiers, landless groups came to occupy the land and to apply for allotment to the local administration. As a member of district and sub district land reform implementation task force, Uttaran used to recommend for those landless people who had identified and recovered khas land and local administration also kept their recommendation and distributed khas land to those landless people. As a result, landless people began to receive their reward or incentives (khas land) for participation in the land distribution process. This also encouraged other landless people of the area in order to participate in the collaboration process. For this cooperation among local administration, Uttaran and landless people, Tala upazila could distribute 1,202.36 acres of land from year 1985 to 1990 . It constitutes about $66 \%$ of total distribution.

In case of Shahzadpur upazila, we can notice the reverse situation of Tala upazila. Before 1993, as there was no civil society organization working for landless people in this upazila, there was no question of cooperation between local administration and civil society for khas land distribution. After 1993, Samata started working in Shahzadpur upazila. But, the working procedure of Samata was somehow different with that of Uttaran. Where Uttaran all the times tried to build a good relationship with local administration and participated in decision making process like selection of beneficiaries for khas land, there Samata occupied them busy for

\footnotetext{
9 Upazila Nirbahi Officer has been interviewed over telephone on April 30, 2011.

${ }^{10}$ Director of Samata has been interviewed over telephone on April 16, 2011.

11 Assistant Commissioner (land) has been interviewed over telephone on April 30, 2011.
} 
building awareness, identifying khas land but was not involved in the selection of beneficiaries for khas land as it was not included in the land distribution committee. Moreover, Samata could not build up an accommodating alliance with local administration. As a result, although the members of Samata identified land but all of them could not receive properties as a reward for identifying or recovering land. As a result, the landless people of other areas did not feel encouraged to become the members of Samata, did not identify land and did not apply for allotment. Consequently, land distribution in this upazila did not acquire much momentum as in the Tala upazila. The effect of a higher level of cooperation will be clearer, if we analyze the relationship between different levels of cooperation and the average land distributions in different periods of both the upazilas. The relationship between level of cooperation and the average land distribution per year are as follows:

Table 1: Level of cooperation and average land distribution in Tala and Shahzadpur upazila

\begin{tabular}{|c|c|c|c|c|c|}
\hline \multicolumn{2}{|c|}{ Tala upazila } & \multicolumn{2}{|c|}{ Shahzadpur upazila } \\
\hline Periods & $\begin{array}{c}\text { Level of } \\
\text { cooperation } \\
\text { cooperation } \\
\text { per year } \\
\text { acres) }\end{array}$ & $\begin{array}{c}\text { Average distribution } \\
\text { distribution per } \\
\text { year } \\
\text { (in } \\
\text { acres) }\end{array}$ \\
\hline $1985-1990$ & High & 200 & \multirow{2}{*}{$1985-1992$} & Noriods \\
\hline $1991-2004$ & Low & 10 & $1993-2009$ & Low & 7 \\
\hline $2005-2006$ & $\begin{array}{c}\text { Cooperation for } \\
\text { preparatory } \\
\text { work }\end{array}$ & 0 & & 12 \\
\hline $2007-2009$ & High & 35 & & \\
\hline
\end{tabular}

Source: Drawn by the author, 2011

In the above table, we see that average land distributions in both the upazilas at the time of low level of cooperation are almost identical (10 acres in Tala and 12 acres in Shahzadpur upazila respectively). But the difference is attributed only to the presence or absence of a high level of cooperation and the latter is clearly the most significant variable. Therefore, we can say that the hypothesis of this study: the higher level of collaboration between local administration and civil society can accelerate the implementation process of land reform program in Bangladesh, has been proved and confirmed.

\section{Conclusions}

The purpose of this study was to find out factor(s) accountable for greater or lesser distribution of government (khas) land among landless and near landless people of different sub districts (upazilas) in Bangladesh. Both the case studies of this research show that the presence or absence of the higher level of collaboration between local administration and civil society has largely affected the distribution of khas land in both the upazilas.

In Tala upazila, distribution of land was relatively high in the periods from 1985 to 1990 and from 2007 to 2009. In these nine years, about $72 \%$ khas land of this upazila had been distributed. The reason was, in those years, local administration, NGO Uttaran and landless people's organizations jointly identified khas land and removed illegal occupiers from the land. Uttaran had initiated the process of collaboration by building awareness among landless and near landless people about their rights to government land, encouraging them to form associations, to identify government land and to apply for the land. At the initial stage, few people formed the associations, identified khas land. Uttaran and landless groups then jointly informed the local administration about illegal occupiers and local administration reciprocated through providing legal notice to illegal occupiers to vacate the land. After providing legal notice, landless groups came to occupy the land and to apply to local administration for the land title. Uttaran assisted them to fill in the application forms as most of them were illiterate. Local administration had distributed the land among those people who had identified and recovered the land. This encouraged other landless people of the upazila in order to follow the process of their own accord.

Administration had also reciprocated the endeavors of Uttaran through involvement of Uttaran in the land distribution committees in 1988. From 1988 to 1990, local administration and Uttaran used to jointly select the eligible landless people for khas land. However, this upazila could not maintain the same level of collaboration in other years. Thus, for the presence of the higher level of collaboration between local administration and civil society organizations, land distribution in this upazila for the above mentioned nine years was high whereas for lack of higher level of collaboration, this upazila could manage to distribute only $11 \%$ of its khas land in the subsequent 18 year period.

In Shahzadpur upazila, neither civil society organizations nor local administration had initiated the collaboration process. Here both of them used to work independently. Although NGO Samata started working in several villages of this upazila in 1993, the operational procedure of Samata was different from that of Uttaran. Consequently, this upazila could not ensure the higher level of collaboration between local administration and civil society organization. For lack of the higher level of cooperation between local administration and civil 
society organizations, Shahzadpur upazila could not distribute as much land as Tala upazila did. Shahzadpur upazila could manage to allocate only $25 \%$ of its khas land among landless and near landless people in the 25 years since its inception as an upazila.

Thus, the above analysis reveals that only the presence or absence of the higher level of cooperation between local administration and civil society can explain the divergent outcomes of land distribution in the two upazilas (sub districts) of Bangladesh. Therefore, we can categorically say that the higher level of collaboration between or among local administration and civil society organizations can accelerate the implementation process of land reform program in Bangladesh. It also demonstrates that local based NGO, which has good relation with landless people, can create and maintain collaborative relation with local administration and perform better than outsider NGO. This is clearly the result of trust towards the local NGO or lack of thereof towards the outsider NGO among landless people. The above discussed findings of the study have two major implications. The implications are: since one of the main purposes of the Ministry of Land in Bangladesh is to ensure distribution of khas land among landless and near landless people in order to improve their standard of living, the ministry should take the necessary steps to make sure that there is a fruitful collaboration between local administration and civil society in every upazila of Bangladesh. In case of collaboration, local administration should give priority to local based organizations rather than to outsiders.

From the study, we can also draw a lesson that is, in developing countries, both public agency and civil society actors separately lack in capacity to carry out fruitful distributive reform. But when they work together, their powerlessness is removed to a great extent and they become competent in order to implement reform policy completely as their interdependence also create a high level of synergy. Moreover, the state-society driven approach (sandwich strategy) encourages the participation of landless people, along with NGOs, in land reform process. As the landless people themselves take part in the process, government officials do not have sufficient opportunities to demand bribe. Thus, it can also contribute to control corruption in land distribution process. Within the legal framework of the country, as this approach can recover government land from rich people (influential people who illegally occupied khas land) and allocate the land to underprivileged people, it can also establish social justice to some extent. Consequently, we can say that collaboration between administration and civil society also promotes participatory development as well as good governance.

\section{Acknowledgement}

I am grateful to Professor Jun Matsunami, Professor Yutaka Katayama and Professor Yuriko Takahashi for their generous support and guidance. I am also thankful to Dr. Thomas Barry, local administration of Tala as well as Shahzadpur sub districts, directors, coordinators and officials of NGO Uttaran and NGO Samata.

\section{References}

\section{Journal Papers:}

[1]. Devine, J. (2002). Ethnography of a policy process: a case study of land redistribution in Bangladesh. Public Administration and Development. Vol. 22: 403-414.

[2]. Sikor, T. and Muler, D. (2009). The limits of state-led land reform: an introduction. World Development. Vol. $8: 1307-1316$

[3]. Bobrow-Strain, A. (2004). (Dis) Accords: the politics of market assisted land reform in Chiapas, Mexico. World Development. Vol. 32, No.6: 887-903.

[4]. Bryden, J. and Geisler, C. (2007). Community based land reform: lesson from Scotland. Land Use Policy. Vol. 24, No.1: 24-34.

[5]. Bouquet, E. (2009). State-led land reform and local institutional change: land titles, land markets and tenure security in Mexican communities. World Development. Vol. 37, No.8:1390-1399.

[6]. Deininger, K. (1999). Making negotiated land reform work: initial experience from Colombia, Brazil and South Africa. World Development. Vol. 27, No.4: 651-672.

[7]. Borras, S. M. (2001). State-society relations in land reform implementation in the Philippines. Development and Change. Vol. 32: 545-575.

[8]. Ansell, C. and Gosh, A. (2007). Collaborative governance in theory and practice. Journal of Public Administration Research and Theory. Vol. 18: 543-571.

[9]. Rosenbaum, A. (2006). Cooperative service delivery: the dynamics of public sector-private sector-civil society collaboration. International Review of Administrative Sciences. Vol.72, No.1: 43-56.

[10]. Budhi, G. S. (2008). Escalating people's participation in rural development through GO- NGO collaboration. Forum Penelitian Agro Ekonomi. Vol. 26, No.1: 58-70.

[11]. White, S. C. (1999). NGOs, civil society and the state in Bangladesh: the politics of representing the poor. Development and Change. Vol. 30: 307-326.

[12]. Evans, P. (1996). Government action, social capital and development: reviewing the evidence on synergy. World Development. Vol. 24, No. 6:1119-1132.

[13]. Wolford, W. (2010). Participatory democracy by default: land reform, social movements and the state in Brazil. The Journal of Peasant Studies. Vol. 37, No.1: 91-109.

Books:

[14]. Chenery, H. B. Jolly, R. Ahluwalia, M. S. Bell, C. L. G. and Duloy, J. H. (1974). Redistribution with growth: policies to improve income distribution in developing countries in the context of economic growth. London: Oxford University Press.

[15]. Barkat, A. Zaman, S. and Raihan, S. (2001). Political economy of khas land in Bangladesh. Dhaka: Association for Land Reform and Development.

[16]. United Nations. (1966). Progress in land reform, third report. Rome: World Land Reform Conference. 
[17]. Tai, H. (1974). Land reform and politics: a comparative analysis. London: University of California Press.

[18]. Raup, M. P. (1975). Land reform issues in development. Minnesota: University of Minnesota.

[19]. Rogers, D. and Whetten, D. (1982). Interorganizational coordination: theory, research and implementation. Ames, Iowa: Iowa State University Press.

[20]. Meera, M. (1996). New trends for the government-NGO partnership in Asia. Mexico: Habitat International Coalition.

[21]. Farrington, J. Lewis, D. J. Satish, S. and Miclat-Teves, A. (1993). Non-governmental organizations and the state in Asia: rethinking roles in sustainable agricultural development. London: Routledge.

[22]. Inter American Foundation. (2001). Building democracy from the grass roots. Washington DC: Inter American Foundation.

[23]. Agranoff, R. and McGuire, M. (2003). Collaborative public management: new strategies for local governments. Washington DC: Georgetown University Press.

[24]. Fox, J. (1993). The politics of food in Mexico: state power and social mobilization. Ithaca, New York: Cornel University Press.

\section{Chapters in Books:}

[25]. Ghimire, K. B. (2001b). Land reform at the end of the twentieth century: an overview of issues, actors and processes. In K. B. Ghimire (ed.) The land reform and peasant livelihoods: the social dynamics of rural poverty and agrarian reform in developing countries. London: ITDG Publishing.

[26]. Barraclough, L. L. (2001). The role of the state and other actors in land reform. In K. B. Ghimire (ed.) The land reform and peasant livelihoods: the social dynamics of rural poverty and agrarian reform in developing countries. London: ITDG Publishing.

[27]. Huizer, G. (2001). Peasant mobilization for land reform: historical case studies and theoretical consideration. In K. B. Ghimire (ed.) The land reform and peasant livelihoods: the social dynamics of rural poverty and agrarian reform in developing countries. London: ITDG Publishing.

[28]. Mannan, M. (2001). South Asia's experience in land reform: the role of NGOs, the state and donors. In K. B. Ghimire and B. H. Moore (eds.) Whose land? civil society perspectives on land reform and rural poverty reduction: regional experiences from Africa, Asia and

[29]. Holland, R. (1985). The new era of public-private partnerships. In P. R. Porter and D.C Sweet (eds.) Rebuilding America's cities: roads to recovery. New Brunswick, New Jersey: Rutgers University Center for Urban.

[30]. Ghimire, K. B. (2001a). Regional perspectives on land reform: considering the role of civil society organizations. In K. B. Ghimire and B. H. Moore (eds.) Whose land? civil society perspectives on land reform and rural poverty reduction: regional experiences from Africa, Asia and Latin America. Rome: International Fund for Agricultural Development.

[31]. Kabir, M. H. (2002). The state and civil society in Bangladesh. In M. R. Khan and M. H. Kabir (eds.) Civil society and democracy in Bangladesh. Dhaka: Academic Press and Publishers Ltd.

[32]. Khan, S. R. (2000). The NGO mixture: seeking the perfect ingredient. In M. Ahmed (ed.)The other option: NGO's and people's praxis. Dhaka: Community Development Library.

[33]. Khan, R. A. and Kabir, F. (2002). Civil society in Bangladesh and its empowerment. In M.R. Khan and M. H. Kabir (eds.) Civil society and democracy in Bangladesh. Dhaka: Academic Press and Publishers Ltd.

Theses:

[34]. Rani, N. (2005). Politics of land reform in post-independence India. Retrieved on June 20, 2010 from Others: http://www.docstoc.com/docs/5543462/Politics-of-Land-Reforms-in-Post-Independence-India.

[35]. Islam, S. (2009). Access to natural productive resources and justice: defending human rights of the marginalized in the southwest coastal Bangladesh. Dhaka: Uttaran.

[36]. World Bank. (1975). Land reform: sector policy paper. Washington DC: World Bank.

[37]. Aga Khan Development Network. (2007). Examining government and CSO collaboration in Kenya: a study of selected succes sful case stories: what can we learn? Retrieved on March 10, 2011 from http://www.akdn.org/publications/civil_society_kenya_cso.pdf.

[38]. Borras, S. M. (2006). Land, empowerment and rural poor: challenges to civil society and development agencies. Rome: International Fund for Agriculture Development.

[39]. Bhatta, G. P. (2010). Assessing land reform approaches to benefit socially and economically disadvantaged (SED) people. Retrieved on March 12, 2011 from http://www.itc.nl/library/papers_2010/msc/la/bhatta.pdf.

[40]. International Fund for Agricultural Development. (n.d.). Empowering the rural poor through access to land. Retrieved on July 08, 2010 from http://www.ifad.org/events /icarrd /factsheet eng.pdf.

[41]. International Land Coalition. (n.d.). Access to land for poverty reduction. Retrieved on $\quad$ December $12, \quad 2010 \quad$ from http://www.landcoalition.org/pdf/cs04ups.pdf.

[42]. Association for Land Reform and Development. (2004). Annual report, 2004. Retrieved on January 15, 2011 from http://www.alrd.org/pdf/ear/English\%20 Annual\%20 Report \% 2004.pdf.

[43]. Islam, S. (2010). Bangladesher daridro o khasjomite bhumihinder odhikar [Poverty of Bangladesh and rights of landless people to government land]. Dhaka: Uttaran. 